\title{
In vitro antimicrobial assessment on lactic acid bacteria isolated from common freshwater fishes
}

\author{
Wai-Wei Chong ${ }^{a}$, Crystale Siew-Ying Limª ${ }^{\text {, }}$ Kok-Song Lai ${ }^{\mathrm{b}}$, Jiun-Yan Loha* \\ ${ }^{a}$ Faculty of Applied Sciences, UCSI University, No. 1, Jalan Menara Gading, UCSI Heights, Cheras, 56000 Kuala Lumpur, Malaysia \\ ${ }^{b}$ Department of Cell and Molecular Biology, Faculty of Biotechnology and Biomolecular Sciences, Universiti Putra Malaysia, 43400 UPM \\ Serdang, Selangor Darul Ehsan, Malaysia
}

Received 2nd November 2018 / Accepted 1st March 2019

\begin{abstract}
Probiotic is well-known as an effective agent to control and manage diseases in aquaculture. Unlike antibiotics and chemotherapeutic agents, probiotic does not trigger the emergence of antibiotic/ chemo-resistant bacteria. This study was aimed to isolate, identify and evaluate lactic acid bacteria from intestines of three common food fish, i.e. tilapia (Oreochromis niloticus), catfish (Clarias gariepinus) and rohu (Labeo rohita). Thirty-four lactic acid isolates were isolated and screened for inhibitory effect against fish pathogens e.g. Escherichia coli, Klebisella pneumoniae, Pseudomonas aeruginosa and Salmonella enterica. Positive antagonists were subsequently tested in haemolytic, salt tolerance and bacteriocin-like inhibitory substances (BLIS) assays. Our results showed only three isolates displayed positive inhibitory effect against all four pathogens. These three isolates were classified as $\gamma$-haemolytic bacteria. Our results revealed that bacterial isolates (T2.1.2 - Pediococcus acidilactici and T2.2.2 - Lactobacillus fermentum) isolated from O. niloticus (tilapia) showed a better adaptation in the range of $0-20 \mathrm{ppt}$; while, the bacteria isolated from L. rohita (R1.1.1 - P. acidilactici) could survive up to $35 \mathrm{ppt}$. These isolates were then identified based on 16S rRNA gene sequences. BLIS data revealed that both $P$. acidilactici and L. fermentum isolated from $O$. niloticus and L. robita could suppress the growth of pathogens with cell density as low as $10^{4} \mathrm{cfu} / \mathrm{ml}$. Our study shows that $P$. acidilactici and $L$. fermentum have the potential to be further explored as biocontrol/probiotic agents in aquaculture.
\end{abstract}

Keywords: aquaculture, lactic acid bacteria, pathogen, probiotic

\section{INTRODUCTION}

Intensive aquaculture often associated with high frequency of diseases outbreak. Fish pathogens such as Aeromonas sp., Edwardsiella sp., Pseudomonas sp. and Vibrio sp. are commonly found to be highly infectious in both freshwater and marine environments (Banerjee and Ray, 2017). The early onset of these symptoms could be associated with fin rot, exophthalmia, and skin ulcers. Infected fish showed a high rate of mortality or stunted growth in the severe stage (Dong et al., 2017;
Fečkaninová et al., 2017).

Antibiotics are the common practices used in many animal productions to manage and control diseases. In aquaculture, antibiotics are administered through the feeds or directly into the water. Although antibiotics are effective in treating fish diseases, the rampant use of an antibiotic can cause negative impacts on the host and the environment (Lazado et al., 2015). Antibiotics increase the emergence of antibiotic-

*Author for correspondence: Jiun-Yan Loh, Faculty of Applied Sciences, UCSI University, No. 1, Jalan Menara Gading, UCSI Heights, Cheras, 56000 Kuala Lumpur, Malaysia. Email - lohjy@ucsiuniversity.edu.my 
resistant bacteria that can tolerate the use of antibiotics, which will in turn, detrimental to the host's health. Therefore, higher concentration or different antibiotics are required to control the infection during the onset of the same disease in the future. Furthermore, antibiotic residues indirectly discharge through excretion, can lead to inevitable stress effects on the environmental microbial community.

Probiotics are live and beneficial microorganisms that modulate intestinal microbial flora in the host. The term probiotic in Greek language "pro bios" means "for life" (Gismondo et al., 1998). Probiotics can be originated from a wide range of bacteria from Gram-negative to Gram-positive species. The important criteria of a group of microbes to be considered as probiotic; it should not be causing any pathogenic effect to the host, and it should be able to enhance the bowel/intestinal health (Banerjee and Ray, 2017). Study by Fečkaninová et al. (2017) showed the application of lactic acid probiotics could reduce Aeromonas infection in salmonids, the host-associated symbiotic relationship not only contribute to the diversity of microbial flora in the gut, but it also improves digestion, growth, stress tolerance and regulate nutritional factors of the hosts (Wang et al., 2008; Lazado et al., 2015).

The present study aimed to discover the potential of intestinal lactic acid bacteria in probiotic development for aquaculture species. Intestinal microflora was isolated from three common food fish included tilapia (Oreochromis niloticus), catfish (Clarias gariepinus) and rohu (Labeo rohita). The bacteria isolates were screened through agar well diffusion assay against Salmonella enterica, Escherichia coli, Klebsiella pneumoniae and Psedomonas aeruginosa. Hemolytic activities and salt tolerance test was used to evaluate the pathogenicity of the probiotics. After multi-screening tests, the potential probiotic candidates were identified based on molecular approach. Bacteriocin-like inhibitory substances (BLIS) assay was performed to determine the minimum inhibitory effect against the pathogens.

\section{MATERIALS AND METHODS}

Sampling of common food fish. Three common food fish $(n=6)$ (Table 1) were purchased from a local fish market at Kuchai Entrepreneurs Park, Kuala Lumpur, Malaysia. Prior to the dissection, the surface body of common food fish was disinfected with $70 \%$ $(\mathrm{v} / \mathrm{v})$ ethanol. The fish were then dissected using a sterile dissecting kit, incision was made from the anus to post-stomach of the fish to remove the intestinal samples for subsequent processes.

\section{Isolation of intestinal microflora from} common food fish. Intestinal samples $(1 \mathrm{~g})$ from each fish were homogenized using an electric homogenizer (LabGEN®125, Cole-Parmar, USA) in deMan, Rogosa, and Sharpe (MRS) broth and incubated for $24 \mathrm{~h}$ at $37 \pm 2^{\circ} \mathrm{C}$. Serial dilution was performed $\left(10^{-1}\right.$ to $\left.10^{-9}\right)$, and $1 \mathrm{~mL}$ from each intestinal sample was spread plated onto MRS agar and incubated for $24 \mathrm{~h}$ at $37 \pm 2^{\circ} \mathrm{C}$. The MRS plates were then incubated at room temperature $\left(26 \pm 2^{\circ} \mathrm{C}\right)$ for $24 \mathrm{~h}$. Pure cultures were collected from single colonies and established on corresponding fresh agar plates. Individual colonies were taken based on morphological differences and subsequently streaked on MRS agar. Pure bacteria were obtained after three times of plate streaking.

In vitro screening for antagonistic bacteria. Bacterial isolates were screened for their antagonistic activity against E. coli, $K$. pneumoniae, $P$. aeruginosa and $S$. enterica (UCSI laboratory's collection, Microbiology Lab in South Wing campus, KL) using agar well diffusion method. Supernatants of overnight bacterial culture were collected by centrifugation at 7,500 rpm for 15 $\mathrm{min}$ at room temperature using a mini-spin centrifuge (MiniSpin ${ }^{\circledR}$ plus, Eppendorf, China). The supernatant of bacteria was then filtered through $0.45 \mu \mathrm{m}$ pore size filter (Sortunos, USA) to obtain cell-free supernatant (CFS). An overnight culture of pathogens was added into 20 $\mathrm{ml}$ of soft nutrient agar (NA) at $37^{\circ} \mathrm{C}$, and mixed before pouring into the Petri dishes. To each agar plate, five wells were prepared using a cork borer with a diameter of $2 \mathrm{~cm}$. Each well was filled with $100 \mathrm{uL}$ of CFS including a blank control of sterile 
MRS broth. The plates were then incubated at $37 \pm 2{ }^{\circ} \mathrm{C}$ for $24 \mathrm{~h}$. The experiment was performed in triplicates. Antimicrobial activity was expressed as the diameter of the inhibition zones formed around the wells. Inhibitory strength was defined as: zone of inhibition $>20 \mathrm{~mm}=$ strong inhibition; 10-20 $\mathrm{mm}=$ intermediate/moderate inhibition; and $<10 \mathrm{~mm}=$ low inhibition (Shokryazdan et al., 2014).

Haemolytic activity assay. Bacteria exhibited positive antimicrobial activity were then streaked onto horse blood agars (Thermo Scientific, Malaysia) and incubated at $37 \pm 2{ }^{\circ} \mathrm{C}$ for $24 \mathrm{~h}$. Haemolysis was classified as $\alpha$-haemolysis, $\beta$ haemolysis and $\gamma$-haemolysis based on red blood cell lysis patterns. Bacteria isolates with only $\gamma$ - haemolysis were selected for subsequent study (Loh et al., 2014).

Salt tolerance assay. Salt tolerance was determined by incubating $\gamma$-haemolytic bacterial isolates in MRS broth containing a various concentration of sodium chloride $(\mathrm{NaCl}$; Merck, Germany). Sodium chloride was supplemented to MRS broth at a different concentration of $0,5,10$, 15, 20, 25, 30 and 35 ppt. Ten mL of MRS broth was used to culture the bacterial isolates in $15 \mathrm{~mL}$ tubes. The experiment was performed in triplicates. Bacterial culture was incubated for 24 $h$ at $37 \pm 2{ }^{\circ} \mathrm{C}$. Optical density was determined at $600 \mathrm{~nm}$ using a UV-spectrophotometer (Eppendorf, Malaysia).

Table 1. Specifications of common food fish specimens $(n=6)$.

\begin{tabular}{cccc}
\hline Common Food Fish & Species Name & Weight $\mathbf{( g )}$ & Length $\mathbf{( c m})$ \\
\hline Catfish & Clarias gariepinus & $334 \pm 10.0$ & $45.2 \pm 3.0$ \\
Rohu & Labeo rohita & $716 \pm 20.2$ & $63.5 \pm 4.5$ \\
Tilapia & Oreochromis niloticus & $480 \pm 12.1$ & $47.8 \pm 2.8$ \\
\hline
\end{tabular}

\section{$16 S$ rRNA characterization of selected} bacterial isolates. Selected bacterial isolates were cultured in MRS broth at $37 \pm 2^{\circ} \mathrm{C}$ for $24 \mathrm{~h}$ prior to DNA extraction. Genomic DNA was extracted using a GF-1 Nucleic Acid extraction kit (Vivantis Tech, Malaysia). The 16S rRNA gene of the extracted DNA was amplified using primers $27 \mathrm{f}$ (5'-AGA GTT TGA TCC TGG CTC AG-3') forward primer and 1492r (5'-GGT TAC CTT GTT ACG ACT T-3') reverse primer to recover nearly full length of the 16S rRNA (Loh et al., 2017). The polymerase chain reaction (PCR) process was performed on $25 \mathrm{uL}$ reaction mixtures containing $2.5 \mu \mathrm{L}$ of extracted DNA, 0.5 $\mu \mathrm{L}$ of $10 \mu \mathrm{M}$ forward primer, $0.5 \mu \mathrm{L}$ of $10 \mu \mathrm{M}$ reverse primer, $2.5 \mu \mathrm{L}$ of $10 \mathrm{X}$ reaction buffer, 0.5 $\mathrm{uL}$ of $10 \mathrm{mM}$ dNTPs, $0.5 \mathrm{uL}$ of $5 \mathrm{U}$ polymerase enzyme, $0.5 \mu \mathrm{l}$ of $25 \mathrm{mM}$ magnesium chloride and 17.5 uL of Milli-Q water. PCR reaction was carried out using the thermal cycler (Eppendorf, Malaysia) with the following parameters: predenaturation at $94^{\circ} \mathrm{C}$ for $5.00 \mathrm{~min}$, followed by 30 cycles of denaturation at $94^{\circ} \mathrm{C}$ for $0.30 \mathrm{~min}$, annealing at $57^{\circ} \mathrm{C}$ for $0.45 \mathrm{~min}$, and extension at $72^{\circ} \mathrm{C}$ for $1.30 \mathrm{~min}$, with a final extension at $72^{\circ} \mathrm{C}$ for $7.00 \mathrm{~min}$. DNA purification was performed in
$50 \mu \mathrm{L}$ of PCR reaction mixture prepared for each bacteria isolate using MEGAquick-spin ${ }^{\text {TM }}$ Total Fragment DNA purification kit (YMS, Korea) prior to bi-directional sequencing using primers $27 \mathrm{f}$ and $1492 \mathrm{r}$. After purification, PCR products were sent for sequencing (MyTACG, Malaysia). The results of gene sequences were analyzed using BioEdit 7.0.5.3 and matched with bacterial sequences in the BLAST (NCBI) database.

BLIS assay. The bacteriocin-like inhibitory substances (BLIS) assay was performed to determine the minimum inhibitory effect of bacteria isolates on the pathogens. the identified bacterial isolates and pathogens were cultured separately in $30 \mathrm{~mL}$ MRS broth and nutrient broth (NB) and subsequently incubated for $24 \mathrm{~h}$ at $37 \pm 2^{\circ} \mathrm{C}$. The intestinal bacterial culture was then adjusted to the densities of $10^{4}, 10^{5}, 10^{6}$ and $10^{7}$ cfu/ml using a microplate reader (Infinite 200 PRO NanoQuant, Switzerland) at $\mathrm{OD}_{540}$. Subsequently, bacterial isolates with various cell densities were streaked onto NA in a single line using a sterile cotton swab. Pathogens at a cell density of $10^{5} \mathrm{cfu} / \mathrm{ml}$ were streaked perpendicularly to the line of the testing bacterial 
isolates of different cell densities (Loh et al., 2014). The inoculated plates were then incubated for 24 $\mathrm{h}$ at $37 \pm 2^{\circ} \mathrm{C}$. The experiment was performed in triplicates. Inhibitory lengths were measured and compared with the control (sterile MRS broth).

Data analysis. Data were analyzed using statistical analyzing software SPSS version 23. One-way analysis variance (ANOVA) was used to compare the means and Tukey's $(\mathrm{p}<0.05)$ to determine the significance of different bacterial activities in agar well diffusion, salt tolerance, and BLIS assay. Statistical significance was accepted at $\mathrm{p}<0.05$.

\section{RESULTS}

A total of 34 bacterial isolates were isolated from the intestinal tract of fish specimens. There were 16 isolates from Clarias gariepinus (catfish), 10 isolates from Labeo rohita (rohu) and eight isolates from Oreochromis niloticus (tilapia). Among these isolates, five isolates showed positive antagonistic activity towards the pathogens tested, with one potential antagonists isolated from C. gariepinus; one potential antagonist from L. robita and three potential antagonists from O. niloticus (Table 2). Out of the five potential antagonists tested for haemolysis. Only three isolates showed $\gamma$ haemolytic activity. The other two bacterial isolates showed either $\alpha$-or $\beta$-haemolytic activity. Only $\gamma$-haemolytic activity was selected for salt tolerance test. Out of three $\gamma$-haemolytic bacterial isolates, two bacterial isolates were originated from $O$. niloticus and one bacterial isolate was isolated from $L$. rohita. None of the bacterial isolates from $C$. gariepinus showed a positive result ( $\gamma$-haemolysis) (Figure 1). Salt tolerance test revealed that all three bacterial isolates were able to grow in a wide range of salt-rich environment, i.e. 15, 30 and $35 \mathrm{ppt}$ (Table 3). Bacterial isolates with $\gamma$-haemolytic activity were characterized using a molecular approach to determine their species. Bacteria isolated from O. niloticus (T2.1.2) and L. robita (R1.1.1) showed $98-100 \%$ similarity to Pediococcus acidilactici. While bacterial isolate (T2.2.2) obtained from O. niloticus showed 99\% similarity to Lactobacillus fermentum (Table 4). P. acidilactici (T2.1.2) and L. fermentum (T2.2.2) were subsequently selected for BLIS assay in this study. The growth of E. coli $\left(10^{5} \mathrm{cfu} / \mathrm{ml}\right)$ was significantly inhibited by $P$. acidilactici at $10^{4} \mathrm{cfu} / \mathrm{ml}$ and $10^{7} \mathrm{cfu} / \mathrm{ml}$. For K. pneumonia, the inhibitory effect exerted by $P$. acidilactici at $10^{4} \mathrm{cfu} / \mathrm{ml}$ was recorded the lowest at $5 \pm 0.82 \mathrm{~mm}$ and the highest at $10^{6} \mathrm{cfu} / \mathrm{ml}(9.67 \pm 0.47 \mathrm{~mm})$. While for $P$. aeruginosa, lowest inhibition was found when treated with $10^{4}$ and $10^{5} \mathrm{cfu} / \mathrm{ml} P$. acidilactici. There is no significant different $(p>0.05)$ of the inhibitory effect showed by different bacterial cell density against the pathogen. On the other hand, different trend was observed in $S$. enterica, moderate inhibition was recorded when pathogen was treated with $10^{7} \mathrm{cfu} / \mathrm{ml} P$. acidilactici (Table 5). In the case of $L$. fermentum, low inhibition was recorded in E. coli treatment, whereby the pathogen showed rather mild suppression in their growth at all concentration. Moderate inhibition was found when $K$. pneumoniae treated with $L$. fermentum at $10^{7} \mathrm{cfu} / \mathrm{ml}(10.67 \pm 0.94 \mathrm{~mm})$, and mild inhibitory effect at $10^{4}$ and $10^{5} \mathrm{cfu} / \mathrm{ml}$, respectively. Likewise, $P$. aeruginosa and $S$. enterica shared the similar inhibitory trend as in $K$. pneumonia, where moderate inhibition was found when these pathogens were treated with $10^{7}$ $\mathrm{cfu} / \mathrm{ml} \mathrm{L}$. fermentum, both recorded at $12.33 \pm 2.10$ and $12.67 \pm 1.25 \mathrm{~mm}$, respectively. Nonetheless, mild inhibition of the pathogens was still observable when treated with $<10^{6} \mathrm{cfu} / \mathrm{ml} \mathrm{L}$. fermentum (Table 6).

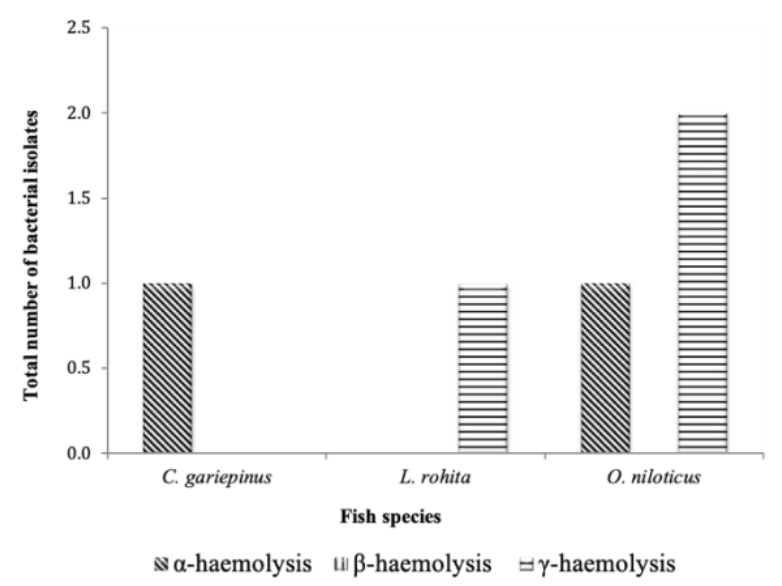

Figure 1. Haemolytic activities of intestinal bacteria isolated from C. gariepinus, L. robita and $O$. niloticus. 
Table 2. Inhibitory effect of potential antagonists against pathogens.

\begin{tabular}{cccccc}
\hline Pathogens & \multicolumn{5}{c}{ Annular radius by bacteria isolates $\mathbf{( c m )}$} \\
\cline { 2 - 6 }$(\mathbf{1 0} \mathbf{c f u} / \mathbf{m l})$ & $\mathbf{T} 2.1 .2$ & $\mathbf{T} 2.2 .1$ & $\mathbf{T} 2.2 .2$ & $\mathbf{R} 1.1 .1$ & $\mathbf{C 1 . 2 . 2}$ \\
\hline E. coli & $1.63 \pm 0.047^{\mathrm{a}}$ & - & $1.83 \pm 0.047 \mathrm{~b}$ & - & - \\
K. pneumoniae & $1.63 \pm 0.047 \mathrm{a}$ & - & $1.57 \pm 0.047 \mathrm{a}$ & $1.13 \pm 0.047 \mathrm{~b}$ & $0.93 \pm 0.047 \mathrm{~b}$ \\
P. aeruginosa & $1.77 \pm 0.047 \mathrm{a}$ & $1.07 \pm 0.094 \mathrm{~b}$ & $1.6 \pm 0.082^{\mathrm{a}}$ & - & - \\
S. enterica & $1.67 \pm 0.047^{\mathrm{a}}$ & - & $1.63 \pm 0.047^{\mathrm{a}}$ & - & - \\
\hline
\end{tabular}

Means ( $\mathrm{n}=3) \pm$ standard deviation; Values with different letters in the same column are significantly different $(\mathrm{p}<0.05)$ among the pathogens; " - " indicates no inhibition. " $T$ " in front of the numbering denotes as Tilapia, " $\mathrm{R}$ " denotes as rohu, " $\mathrm{C}$ " denotes as catfish.

Table 3. Growth performance of bacterial isolates exposed under various $\mathrm{NaCl}$ concentrations.

\begin{tabular}{cccc}
\hline \multirow{2}{*}{ Salinity (ppt) } & \multicolumn{3}{c}{ Absorbance (nm) of bacterial isolates } \\
\cline { 2 - 4 } & T2.1.2 & T2.2.2 & R1.1.1 \\
\hline 0 & $2.592 \pm 0.189 \mathrm{bc}$ & $2.392 \pm 0.037^{\mathrm{a}}$ & $2.295 \pm 0.032^{\mathrm{ab}}$ \\
5 & $2.653 \pm 0.029 \mathrm{c}$ & $2.495 \pm 0.038^{\mathrm{a}}$ & $2.231 \pm 0.013^{\mathrm{ab}}$ \\
10 & $2.503 \pm 0.017 \mathrm{abc}$ & $2.417 \pm 0.010^{\mathrm{a}}$ & $2.216 \pm 0.094^{\mathrm{ab}}$ \\
15 & $2.536 \pm 0.006^{\mathrm{abc}}$ & $2.519 \pm 0.07^{\mathrm{a}}$ & $2.312 \pm 0.070^{\mathrm{b}}$ \\
20 & $2.587 \pm 0.031^{\mathrm{bc}}$ & $2.512 \pm 0.045^{\mathrm{a}}$ & $2.247 \pm 0.044^{\mathrm{ab}}$ \\
25 & $2.415 \pm 0.024^{\mathrm{abc}}$ & $2.488 \pm 0.077^{\mathrm{a}}$ & $2.190 \pm 0.013^{\mathrm{ab}}$ \\
30 & $2.339 \pm 0.017^{\mathrm{a}}$ & $2.416 \pm 0.022^{\mathrm{a}}$ & $2.151 \pm 0.013^{\mathrm{a}}$ \\
35 & $2.372 \pm 0.004^{\mathrm{ab}}$ & $2.419 \pm 0.020^{\mathrm{a}}$ & $2.232 \pm 0.009^{\mathrm{a}}$ \\
\hline
\end{tabular}

Means $(n=3) \pm$ standard deviation; Values with different letters in the same column are significantly different $(\mathrm{p}<0.05)$ among different salinities. "T" if front of the numbering denotes as Tilapia, "R" denotes as rohu, "C" denotes as catfish.

Table 4. Bacterial identification through $16 \mathrm{~S}$ rRNA partial sequences genes.

\begin{tabular}{cccccc}
\hline No. & Isolate & Host & Bacterial species & Strain & $\begin{array}{c}\text { Max. identity } \\
\mathbf{( \% )}\end{array}$ \\
\hline 1. & T2.1.2 & O. niloticus & Pediococcus acidilactici & ML96 & $100 \%$ \\
2. & T2.2.2 & O. niloticus & Lactobacillus fermentum & NWAFU1463 & $99 \%$ \\
3. & R1.1.1 & L. rohita & Pediococcus acidilactici & JFP1 & $98 \%$ \\
\hline
\end{tabular}

Table 5. Inhibitory effect of Pediococcus acidilactici.

\begin{tabular}{ccccc}
\hline Cell density of bacteria & \multicolumn{4}{c}{ Length of inhibition against pathogens $(\mathbf{m m})$} \\
\cline { 2 - 5 } (cfu/ml) & $\boldsymbol{E}$. coli & $\boldsymbol{K}$. pneumoniae & $\boldsymbol{P}$. aeruginosa & $\boldsymbol{S}$. enterica \\
\hline $0($ Control $)$ & - & - & - & - \\
$10^{4}$ & $3.67 \pm 0.471^{\mathrm{a}}$ & $5 \pm 0.816^{\mathrm{a}}$ & $7 \pm 1.414^{\mathrm{a}}$ & $6.33 \pm 0.471^{\mathrm{a}}$ \\
$10^{5}$ & $4.67 \pm 1.247^{\mathrm{a}}$ & $8 \pm 1.633^{\mathrm{ab}}$ & $7 \pm 0.816^{\mathrm{a}}$ & $7 \pm 0.816^{\mathrm{a}}$ \\
$10^{6}$ & $6.67 \pm 1.886^{\mathrm{ab}}$ & $9.67 \pm 0.471^{\mathrm{b}}$ & $10.33 \pm 2.055^{\mathrm{a}}$ & $8.67 \pm 1.247_{\mathrm{ab}}$ \\
$10^{7}$ & $9.67 \pm 0.943^{\mathrm{b}}$ & $9.33 \pm 1.700^{\mathrm{b}}$ & $11.33 \pm 0.943^{\mathrm{a}}$ & $10 \pm 0.816^{\mathrm{b}}$ \\
\hline
\end{tabular}

Means ( $\mathrm{n}=3) \pm$ standard deviation; Values with different letters in the same column are significantly different $(\mathrm{p}<0.05)$ among the bacterial cell densities. All pathogenic concentration was set at $10^{5} \mathrm{cfu} / \mathrm{ml}$. Zone of inhibition $>20 \mathrm{~mm}=$ strong inhibition; $10-20 \mathrm{~mm}=$ intermediate $/$ moderate inhibition; and $<10 \mathrm{~mm}=$ low inhibition.

Table 6. Inhibitory effect of Lactobacillus fermentum.

\begin{tabular}{ccccc}
\hline Cell density of bacteria & \multicolumn{4}{c}{ Length of inhibition against pathogens $(\mathbf{m m})$} \\
\cline { 2 - 5 } (CFU / ml) & $\boldsymbol{E}$. coli & $\boldsymbol{K}$. pneumoniae & $\boldsymbol{P}$. aeruginosa & $\boldsymbol{S}$. enterica \\
\hline $0($ Control $)$ & - & - & - & - \\
$10^{4}$ & $5 \pm 0.816^{\mathrm{ab}}$ & $4.67 \pm 2.357^{\mathrm{a}}$ & $6.67 \pm 0.943^{\mathrm{a}}$ & $6.33 \pm 0.471^{\mathrm{a}}$ \\
$10^{5}$ & $4.67 \pm 0.943^{\mathrm{a}}$ & $4.67 \pm 0.943^{\mathrm{a}}$ & $6.33 \pm 0.471^{\mathrm{a}}$ & $6.33 \pm 0.943^{\mathrm{a}}$ \\
$10^{6}$ & $8.33 \pm 1.247 \mathrm{bc}$ & $7.33 \pm 0.471^{\mathrm{ab}}$ & $7.67 \pm 0.471^{\mathrm{a}}$ & $9.67 \pm 1.247 \mathrm{~b}$ \\
$10^{7}$ & $9.67 \pm 1.247^{\mathrm{c}}$ & $10.67 \pm 0.943^{\mathrm{b}}$ & $12.33 \pm 2.055^{\mathrm{b}}$ & $12.67 \pm 1.247^{\mathrm{b}}$ \\
\hline
\end{tabular}

Means ( $\mathrm{n}=3) \pm$ standard deviation; Values with different letters in the same column are significantly different $(\mathrm{p}<0.05)$ among the bacterial cell densities. All pathogenic concentration was set at $10^{5} \mathrm{cfu} / \mathrm{ml}$. Zone of inhibition $>20 \mathrm{~mm}=$ strong inhibition; $10-20 \mathrm{~mm}=$ intermediate $/$ moderate inhibition; and $<10 \mathrm{~mm}=$ low inhibition. 


\section{DISCUSSION}

Among 34 bacteria isolates, only five isolates showed weak to intermediate inhibitory activity towards pathogens i.e. E. coli, $K$. pneumoniae, $P$. aeruginosa and $S$. enterica. Although catfish had the highest number of bacteria isolates, however, only one bacteria isolate was found to have weak inhibitory activity towards the pathogens. On the other hand, tilapia possessed the highest number of bacteria isolates that showed an intermediate inhibitory effect against the pathogens.

Haemolytic assay further tested the suitability of the bacterial isolates and their haemolytic properties. Haemolysis is a resultant of red blood cells breakdown caused by pathogenic bacteria (Sowemimo-Coker, 2002). In the present study, of the five bacterial isolates, only three isolates showed $\gamma$-haemolysis. Two isolates showed $\alpha$ haemolysis and none of the bacterial isolate showed $\beta$-haemolysis. The haemolytic assay is a safety measure that can reduce/eliminate suspected pathogens during the screening process in probiotic development. Any bacteria displayed $\alpha-/ \beta$-haemolysis activity would not be considered as they may potentially to cause immunological diseases or malfunction in the defence system of fish (Loh et al., 2014).

The salt tolerance level of three bacterial isolates was further tested at $0-35 \mathrm{ppt}$. The assay aimed to understand survivorship of the bacteria in the presence of salt content. The outcome of the assay could further elucidate the feasibility of these probiotic's application in the marine environment setting. The tolerance level of selected potential probiotics was determined through salt tolerance assay in the study. An increment of turbidity signifying a growing number of bacteria in this case (Walter and Deborah, 1952). According to Wong and Rawls (2012), the intestinal environment of a host is largely dependent on its ambient living condition; which implies that intestinal microbiota composition of fish could be significantly influenced by their living habitat. However, our result showed that microflora isolated from freshwater fish's intestines could also survive in a broad range of salinity. Two bacterial isolates were identified as P. acidilactici (Strain ML96: O. niloticus; Strain JFP1: L. rohita), and one bacterial isolate was L. fermentum (Strain NWAFU1463: O. niloticus) through $16 \mathrm{~S}$ rRNA sequence identification. In our case, Pediococcus acidilactici (T2.1.2) isolated from $O$. niloticus (tilapia) showed a better adaptation in the range of 0-20 ppt; however, Lactobacillus fermentum (T2.2.2) isolated from the same species, survived the best at the range of $5-20$ ppt. On the other hand, $P$. acidilactici (R1.1.1) isolated from Labeo robita (rohu) could adapt from $0-35 \mathrm{ppt}$ (Table 3). Our result showed that $P$. acidilactici originated from different host's intestines could strive at a different level of salinity. It is interesting to note that, these bacterial isolates have no doubt to survive in the environment of higher salinity. Our findings somehow were in the agreement with the findings of Wong and Rawls (2012), where intestinal bacteria could tolerate different salinities like their hosts. For instances, O. niloticus survive in a wide range of salinity e.g. $0-25 \mathrm{ppt}$ (Watanabe et al., 1985) while L. robita survive $<12$ ppt (Islam et al., 2014). Some literates also indicated that certain lactic acid bacteria (LAB) able to tolerate different temperatures, salt contained environment and a wide range of $\mathrm{pH}$ (Papadimitriou et al., 2016). According to Justé et al. (2014), Tetragenococcus spp. could survive in the extreme high salt environment $(25 \%(\mathrm{w} / \mathrm{v})$ or 250 ppt). However, high salt concentration could induce osmotic stress in certain LABs e.g. $L$. delbrueckii subsp. lactis, which can kill the bacteria through autolytic activity (Koch et al., 2007). Thus, it is important to understand the salt tolerance level of proposed probiotic candidates to ensure the effectiveness of its application in various fish species, especially to species inhabiting at intertidal zones or estuaries (Cahill, 1990; Balcázar et al., 2008; Das et al., 2008).

BLIS assay results showed that $P$. acidilactici and $L$. fermentum were able to suppress the growth of E. coli, K. pneumoniae, P. aeruginosa and S. enterica, treated with LAB's cell density as low as $10^{4}$ $\mathrm{cfu} / \mathrm{ml}$ within 24 hours of application. Pathogenic concentration was set at $10^{5} \mathrm{cfu} / \mathrm{ml}$ in this study. The infectious concentration of pathogen to its host is varying among host's species, likewise, it also depends on pathogenic species. In general, pathogens that causing fish disease could be as low as $10^{5} \mathrm{cfu} / \mathrm{ml}$ (Schmid-Hempel and Frank, 2007). Other BLIS producing bacteria e.g. Bacillus subtilis, B. methylotrophicus, Enterococcus faecium, L. fermentum and L. plantarum are abundantly found in 
freshwater fish's intestines (e.g. common carp, catla, snakehead and tilapia). They are able to suppress the growth of many pathogenic bacteria in aquaculture such as $A$. bydrophila, $P$. aeruginosa and S. putrefaciens (Cai et al., 1999; Del'Duca et al., 2013; Mukherjee and Ghosh, 2014). A recent study by Loh et al. (2018), showed that incorporation of LAB e.g. Lactococcus lactis subsp. lactis in live feed (e.g. Artemia) could significantly reduce the occurrence of edwardsiellosis in fish farming. This evidence further emphasizes the need for probiotic to improve the immune system of fish larvae, in order to reduce the mortality rate during the early stages.

For the past few decades, probiotic has been using for disease prophylactic control and management in aquaculture. Among the probiotic candidates, LABs are the most common probiotics used in fish farming to improve overall health status and to reduce the outbreak of diseases in fish. Two probiotic candidates proposed in the present study i.e. P. acidilactici and L. fermentum can be considered as a potential probiotic in aquaculture. It is also interesting to note that, $P$. acidilactici was recently suggested as a potential probiotic in the food industry (Barbosa et al., 2015). While, solid shreds of evidence showed that $L$. fermentum isolated from snakehead fish displayed positive inhibitory activity against several fish pathogens such as $A$. hydrophila, $P$. aeruginosa and $S$. putrefaciens (Allameh et al., 2013). Our preliminary results support the fact that the inclusion of $P$. acidilactici and $L$. fermentum as functional foods in a dietary formulation is viable for the aquaculture industry.

\section{CONCLUSION}

In conclusion, $P$. acidilactici and $L$. fermentum isolated from food fish able to control against human-fish pathogens with the cell density as low as $10^{4} \mathrm{cfu} / \mathrm{ml}$. Overall, our results indicate that $P$. acidilactici and $L$. fermentum could be potentially used in fish diet formulation. However, in vivo tests are still required to validate the efficacy of its application on living hosts.

\section{ACKNOWLEDGEMENT}

The study was financially supported by CERVIE grant (Proj-In-FAS-031) from the UCSI University, Malaysia. The authors would like to express their gratitude to the staff in Microbiology and Biotechnology Lab, UCSI University, Malaysia for their genuine technical supports.

\section{REFERENCES}

Allameh, S., Yusoff, F., Daud, H., Ringø, E., Ideris, A., \& Saad, C. 2013. Characterization of a probiotic Lactobacillus fermentum isolated from Snakehead, Channa striatus, stomach. Journal of the World Aquaculture Society 44(6): 835-844.

Balcázar, J., Vendrell, D., de Blas, I., Ruiz-Zarzuela, I., Muzquiz, J., \& Girones, O. 2008. Characterization of probiotic properties of lactic acid bacteria isolated from intestinal microbiota of fish. Aquaculture 278(1-4): 188-191.

Banerjee, G. \& Ray, A. 2017. The advancement of probiotics research and its application in fish farming industries. Research in Veterinary Science 115: 66-77.

Barbosa, J., Borges, S., \& Teixeira, P. 2015. Pediococcus acidilacticias a potential probiotic to be used in food industry. International Journal of Food Science \& Technology 50(5): 1151-1157.

Cahill, M. 1990. Bacterial flora of fishes: A review. Microbial Ecology 19(1): 21-41.

Cai, Y., Suyanandana, P., Saman, P., \& Benno, Y. 1999. Classification and characterization of lactic acid bacteria isolated from the intestines of common carp and freshwater prawns. The Journal of General and Applied Microbiology 45(4): 177-184.

Das, S., Ward, L., \& Burke, C. 2008. Prospects of using marine actinobacteria as probiotics in aquaculture. Applied Microbiology and Biotechnology 81(3): 589-589.

Del'Duca, A., Cesar, D., \& Abreu, P. 2013. Bacterial community of pond's water, sediment and in the guts of tilapia (Oreochromis niloticus) juveniles characterized by fluorescentin situhybridization technique. Aquaculture Research 46(3): $707-$ 715.

Dong, H., Taengphu, S., Sangsuriya, P., Charoensapsri, W., Phiwsaiya, K., Sornwatana, T., Khunrae, P., Rattanarojpong, T., \& Senapin, S. 2017. Recovery of Vibrio barveyi from scale drop and muscle necrosis disease in farmed barramundi, Lates calcarifer in Vietnam. Aquaculture 473: 89-96.

Fečkaninová, A., Koščová, J., Mudroňová, D., Popelka, P., \& Toropilová, J. 2017. The use of probiotic bacteria against Aeromonas infections in salmonid aquaculture. Aquaculture 469: 1-8.

Gismondo, M., Drago, L., \& Lombardi, A. 1998. Review of probiotics available to modify gastrointestinal flora. Antimicrobics and Infectious Diseases Newsletter 17(10): 79.

Islam, M., Ahsan, D. A., Mandal, S. C., \& Hossain A. 2014. Effects of salinity changes on growth performance and survival of rohu fingerlings, Labeo robita (Hamilton, 1822). Journal of Coastal Development 17: 379.

Justé, A., Lievens, B., Rediers, H., \& Willems, K. 2014. The genus Tetragenococcus. In: Lactic Acid Bacteria: Biodiversity and Taxonomy. Holzapfel, W.H. and Wood, J.B.B. (eds). John Wiley \& Sons, Ltd. pp. 213-227. 
Koch, S., Oberson, G., Eugster-Meier, E., Meile, L., \& Lacroix, C. 2007. Osmotic stress induced by salt increases cell yield, autolytic activity, and survival of lyophilization of Lactobacillus delbrueckii subsp. lactis. International Journal of Food Microbiology 117(1): 36-42.

Lazado, C., Caipang, C., \& Estante, E. 2015. Prospects of hostassociated microorganisms in fish and penaeids as probiotics with immunomodulatory functions. Fish and Shellfish Immunology 45(1): 2-12.

Loh, J. Y., Kay, G. L., \& Ting, A. S. Y. 2018. Bioencapsulation and colonization characteristics of Lactococcus lactis subsp. lactis CF4MRS in Artemia franciscana: a biological approach for the control of Edwardsiella tarda in larviculture. Marine Biotechnology 20(3): 353-362.

Loh, J. Y., Lim, Y .Y., Harmin, S. A., \& Ting, A. S. Y. 2014. In vitro assessment on intestinal microflora from commonly farmed fishes for control of the fish pathogen Edwardsiella tarda. Turkish Journal of Veterinary and Animal Sciences 38: 257-263.

Mukherjee, A. \& Ghosh, K. 2014. Antagonism against fish pathogens by cellular components and verification of probiotic properties in autochthonous bacteria isolated from the gut of an Indian major carp, Catla catla (Hamilton). Aquaculture Research 47(7): 2243-2255.

Papadimitriou, K., Alegría, Á., Bron, P., de Angelis, M., Gobbetti, M., Kleerebezem, M., Lemos, J., Linares, D., Ross, P., Stanton, C., Turroni, F., van Sinderen, D., Varmanen, P., Ventura, M., Zúñiga, M., Tsakalidou, E., \& Kok, J. 2016. Stress Physiology of Lactic Acid Bacteria. Microbiology and Molecular Biology Reviews 80(3): 837-890.

Schmid-Hempel, P. \& Frank, S. 2007. Pathogenesis, virulence, and infective dose. PLoS Pathogens 3(10): 147.

Shokryazdan, P., Sieo, C., Kalavathy, R., Liang, J., Alitheen, N., Faseleh Jahromi, M., \& Ho, Y. 2014. Probiotic potential of lactobacillus strains with antimicrobial activity against some human pathogenic strains. BioMed Research International 2014: 1-16.

Sowemimo-Coker, S. 2002. Red blood cell hemolysis during processing. Transfusion Medicine Reviews 16(1): 46-60.

Walter, K. \& Deborah, K. 1952. Turbidimetric estimation of number of bacteria. American Journal of Clinical Pathology 22 (12): 1181-1185.

Wang, Y., Tian, Z., Yao, J., \& Li, W. 2008. Effect of probiotics, Enteroccus faecium, on tilapia (Oreochromis niloticus) growth performance and immune response. Aquaculture 277(3-4): 203-207.

Watanabe, W.O., Kuo, C-M., \& Huang, M-C. 1985. Salinity tolerance of Nile tilapia fry (Oreochromis niloticus), spawned and hatched at various salinities. Aquaculture 48(2): 159-176.

Wong, S. \& Rawls, J. 2012. Intestinal microbiota composition in fishes is influenced by host ecology and environment. Molecular Ecology 21(13): 3100-3102. 